CHAPTER 4

\title{
SEDIMENTARY PETROLOGY AND RESERVOIR QUALITY OF THE MIDDLE JURASSIC RED GLACIER FORMATION, COOK INLET FOREARC BASIN: INITIAL IMPRESSIONS
}

\author{
Kenneth P. Helmold ${ }^{1}$, David L. LePain ${ }^{2}$, and Richard G. Stanley ${ }^{3}$
}

\section{INTRODUCTION}

The Division of Geological \& Geophysical Surveys and Division of Oil \& Gas are currently conducting a study of the hydrocarbon potential of Cook Inlet forearc basin (Gillis, 2013, 2014; LePain and others, 2013; Wartes, 2015 ; Herriott, 2016 [this volume]). The Middle Jurassic Tuxedni Group is recognized as a major source of oil in Tertiary reservoirs (Magoon, 1994), although the potential for Tuxedni reservoirs remains largely unknown. As part of this program, five days of the 2015 field season were spent examining outcrops, largely sandstones, of the Middle Jurassic Red Glacier Formation (Tuxedni Group) approximately $6.4 \mathrm{~km}$ northeast of Johnson Glacier on the western side of Cook Inlet (fig. 4-1). Three stratigraphic sections (fig. 4-2) totaling approximately $307 \mathrm{~m}$ in thickness were measured and described in detail (LePain and others, 2016 [this volume]). Samples were collected for a variety of analyses including palynology, Rock-Eval pyrolysis, vitrinite reflectance, detrital zircon geochronology, and petrology. This report summarizes our initial impressions of the petrology and reservoir quality of sandstones encountered in these measured sections. Interpretations are based largely on hand-lens observations of hand specimens and are augmented by stereomicroscope observations. Detailed petrographic (point-count) analyses and measurement of petrophysical properties (porosity, permeability, and grain density) are currently in progress.

\section{FRAMEWORK MINERALOGY AND PROVENANCE}

Red Glacier sandstones are almost exclusively volcanic litharenites that are very-fine- to coarse-grained and moderately to poorly sorted. The rock framework typically consists of 60-80 percent dark grains (figs. 4-3A and 4-B) interpreted to be largely volcanic rock fragments (VRFs). Amphiboles and/or pyroxenes constitute a minor portion of the dark grains. Light-colored grains comprise 20-40 percent of the framework and consist largely of plagioclase as suggested by occasional tabular, lath-shaped crystals. Most of the sandstones contain very little, if any, detrital quartz. The prevalence of VRFs, amphiboles/pyroxenes, and plagioclase suggests the sandstones are volcanogenic and were probably derived from an undissected volcanic arc terrane (Dickinson and Suczek, 1979; Dickinson, 1985). It is hypothesized that the detritus was derived almost exclusively from the erosion of pre-existing volcanic rocks, likely including lava flows, ignimbrites, and tuffs, in close proximity to the depocenter. The source terrane for the Red Glacier sandstones was probably a region of uplifted Lower Jurassic Talkeetna Formation (Bull, 2014; Bull, 2015) west of the Bruin Bay fault (Detterman and Hartsock, 1966).

Sandstones in the lower portion of section 1 (30.4-33.2 $\mathrm{m}$ in section) are notably different from the sandstones described above in that they contain a much higher proportion of light-colored grains, largely plagioclase (figs. 4-3C and 4-D). Minor $\mathrm{K}$-feldspar may be present, but it is difficult to distinguish between the two feldspars in hand specimen. Detrital quartz also appears to be present in minor amounts. One possible explanation for the different mineralogy in these samples is that they contain syndepositionally erupted silicic tephra from an active volcanic center in addition to detritus derived from pre-existing volcanic rocks. A more thorough examination of these samples, including the petrographic evaluation of thin sections, should be able to confirm or refute this hypothesis.

\section{RESERVOIR QUALITY}

The mixture of abundant VRFs, amphibole/pyroxene, and plagioclase results in a labile framework mineralogy that is highly susceptible to chemical diagenetic alteration. In addition, experimental studies have shown that weathered basaltic detritus becomes extremely ductile and highly susceptible to grain deformation upon even moderate burial (Pittman and Larese, 1991). Due to the high VRF content, authigenic clays (probably chlorite), and zeolites (probably heulandite) are anticipated to be common cements that occlude the primary pore system and result in poor reservoir quality. Examination of hand specimens reveals very little, if any, intergranular porosity and the sporadic occurrence of a white, non-calcareous cement, probably a zeolite (figs. 4-3E and 4-F). Given the Middle Jurassic age of the sandstones ( $170 \mathrm{~m}$. y.) and the combination of a chemically and mechanically unstable framework, it is unlikely that significant conventional reservoirs exist in the Red Glacier Formation. However, due to the possibility of extensive authigenic clay cement, the Red Glacier sandstones could

\footnotetext{
${ }^{1}$ Alaska Division of Oil \& Gas, 550 W. $7^{\text {th }}$ Ave., Suite 800, Anchorage, AK 99501-3560; kenneth.helmold@alaska.gov

${ }^{2}$ Alaska Division of Geological \& Geophysical Surveys, 3354 College Rd., Fairbanks, AK 99709-3707

${ }^{3}$ U.S. Geological Survey, 345 Middlefield Rd., MS 969, Menlo Park, CA 94025
} 


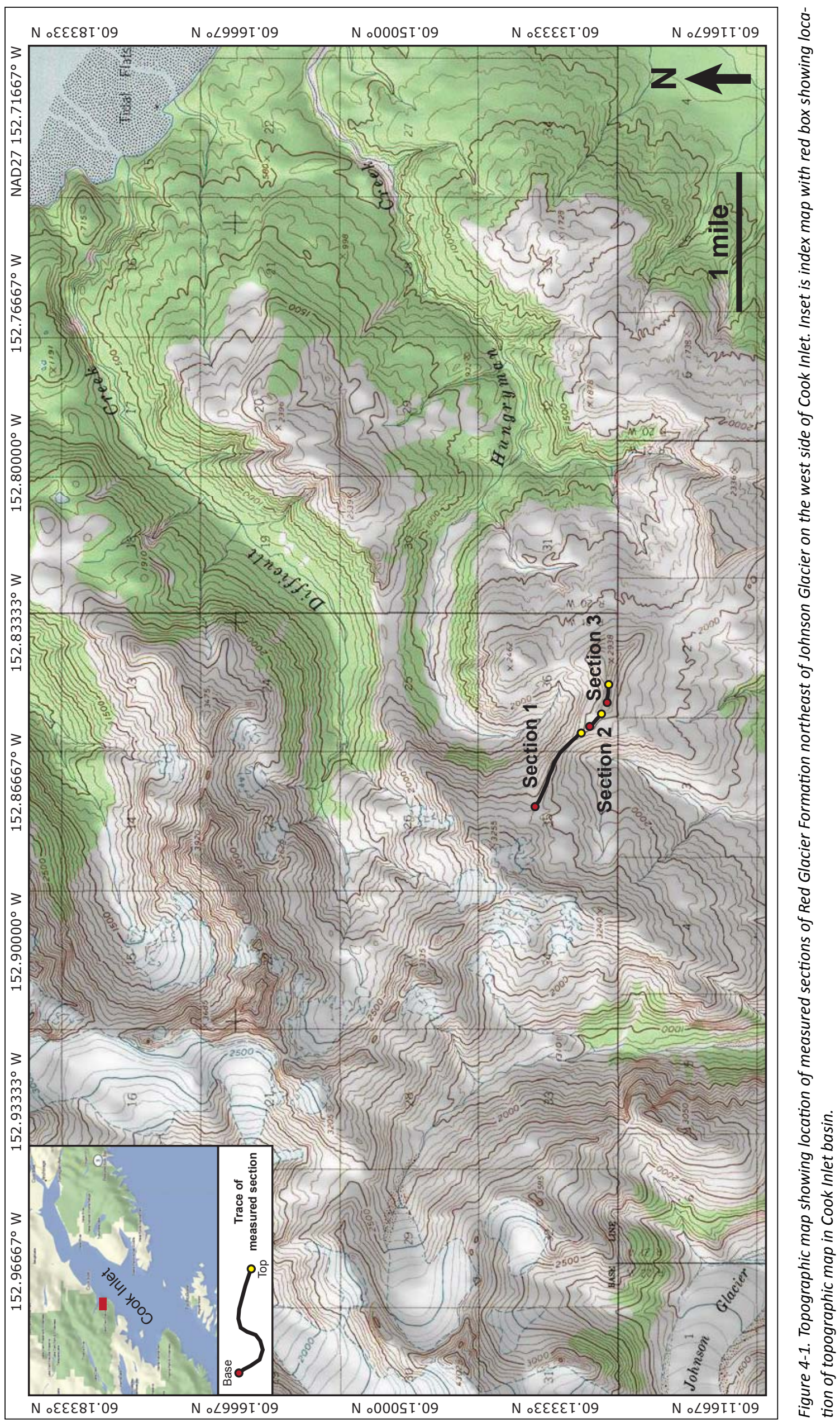




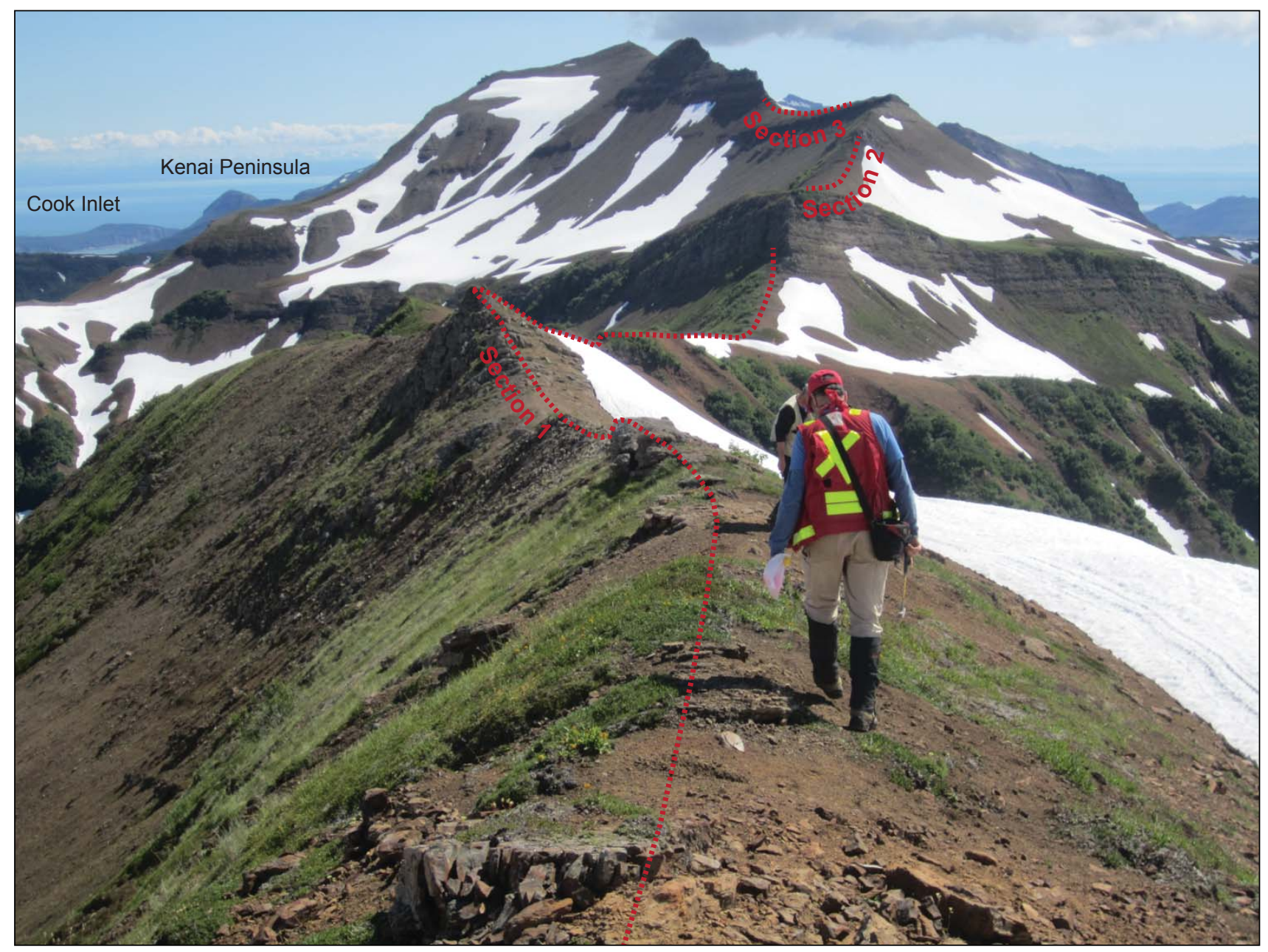

Figure 4-2. View southeastward of the three measured sections of Red Glacier Formation along ridge crest. Lithologies consist largely of fine- to coarse-grained sandstone with minor interbedded siltstone. Geologists for scale.

have potential as tight-gas reservoirs. The interfingering of tight sandstones and potential source rocks of the Red Glacier Formation (LePain and Stanley, 2015) also suggests the possibility of this formation to host continuous oil accumulations, perhaps analogous to those in the Late Devonian and Early Mississippian Bakken Formation of North Dakota (Nordeng, 2009). A similar possibility has been suggested for the overlying Gaikema Sandstone (Helmold and Stanley, 2015). Additional analyses from a larger geographic area are needed before making sweeping conclusions regarding the regional reservoir potential of the Red Glacier Formation.

\section{ACKNOWLEDGMENTS}

Funding for this work was provided by the State of Alaska, with additional financial support from Apache Corporation. Field work was partly funded by the National Cooperative Geologic Mapping Program, administered by the U.S. Geological Survey (STATEMAP awards G13AC00157 and G15AC00199). We gratefully acknowledge the following organizations for granting land access: Lake Clark National Park \& Preserve; Cook Inlet Region, Inc; and Chickaloon, Knik, Ninilchik, Salamatof, Seldovia, and Tyonek Native village corporations. We are grateful to Merlin "Spanky" Handley of Pathfinder Aviation for safely transporting us in the field. We thank the owners and staff of the Snug Harbor Wilderness Lodge on Chisik Island for their hospitality and making us feel welcome during our stay. We thank Trystan M. Herriott and Nina T. Harun for helpful reviews of the manuscript. 

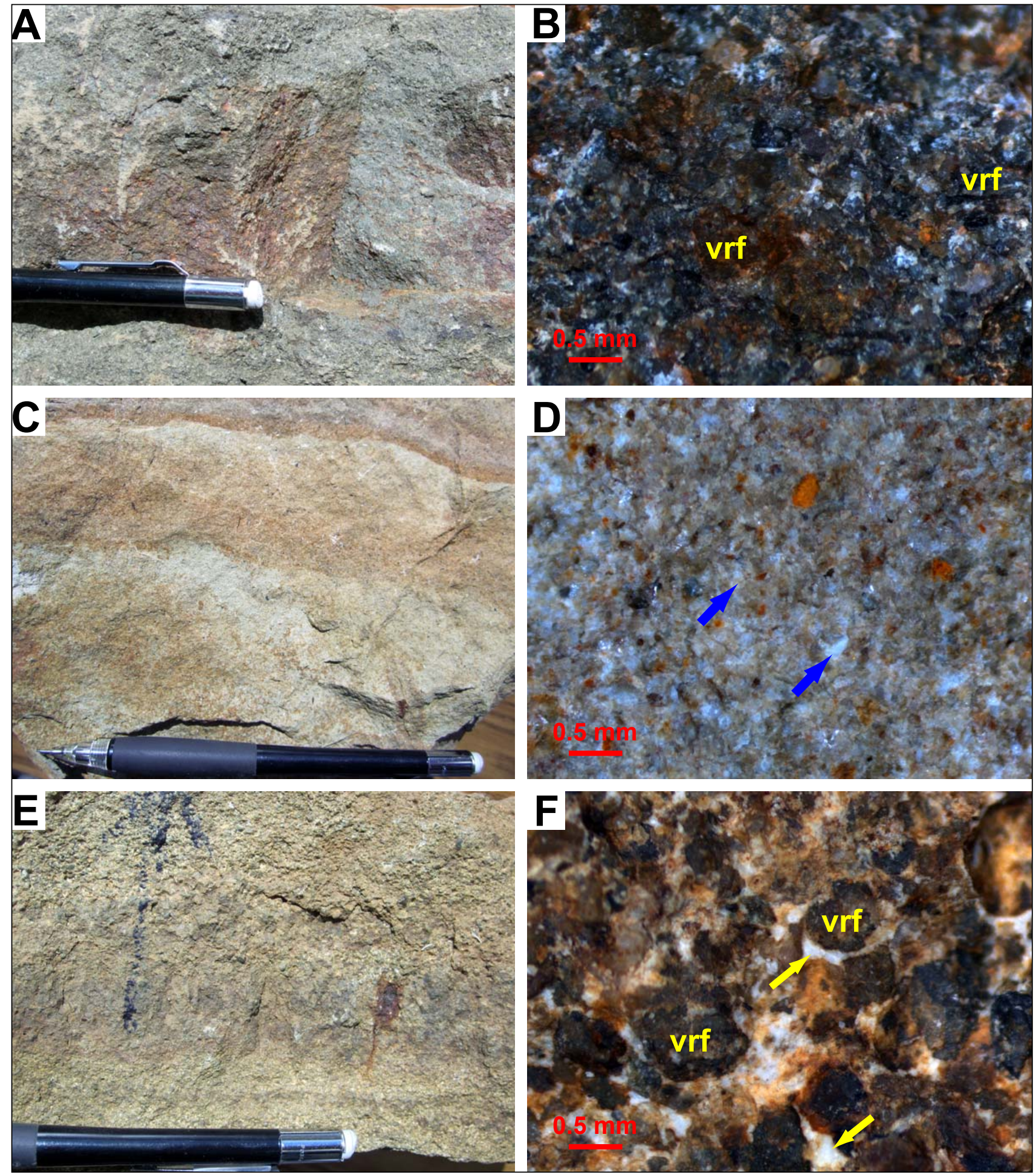

Figure 4-3. Photographs of Red Glacier sandstones from measured section 1. A. Upper fine- to lower medium-grained, poorly-sorted, gray-green-colored sandstone consisting largely of volcanic rock fragments (VRFs). Hand specimen photograph; $187.5 \mathrm{~m}$ in section. B. Same sample as $A$, showing rock framework consisting predominantly of dark-colored, subangular to subrounded VRFs. Stereomicrograph; $187.5 \mathrm{~m}$ in section. C. Upper very-fine-grained, moderately-well-sorted, tan-colored sandstone consisting largely of euhedral to subhedral plagioclase crystals and minor detrital quartz. Hand specimen photograph; $30.4 \mathrm{~m}$ in section. D. Same sample as $C$, showing rock framework consisting predominantly of light-colored, angular to subangular, plagioclase grains (arrows). Orange grains are oxidized mafic components. Stereomicrograph; $30.4 \mathrm{~m}$ in section. E. Lower to upper medium-grained, poorly-sorted, tan-green-colored sandstone consisting largely of VRFs. Hand specimen photograph; $196.6 \mathrm{~m}$ in section. F. Same sample as E, showing white, non-calcareous, probably zeolite cement (arrows) filling intergranular pores between subrounded VRFs. Stereomicrograph; $196.6 \mathrm{~m}$ in section. 


\section{REFERENCES CITED}

Bull, K.F., 2014, Preliminary observations-A facies architecture study of the Lower Jurassic Talkeetna Formation, Iniskin Peninsula, Alaska, in Gillis, R.J., ed., Cook Inlet program 2013 field studies-Observations and preliminary interpretations from new 1:63,360-scale geologic mapping of the Iniskin Peninsula, lower Cook Inlet, Alaska: Alaska Division of Geological \& Geophysical Surveys Preliminary Interpretive Report 2014-2-3, p. 13-16. doi:10.14509/27308

Bull, K.F., 2015, Preliminary observations-Continued facies analysis of the Lower Jurassic Talkeetna Formation, north Chinitna Bay, Alaska, in Wartes, M.A., ed., Energy-related studies of the 2014 field season, western Cook Inlet, Alaska: Alaska Division of Geological \& Geophysical Surveys Preliminary Interpretive Report 2015-5-4, p. 15-22. doi:10.14509/29459

Detterman, R.L., and Hartsock, J.K., 1966, Geology of the Iniskin-Tuxedni Peninsula region, Alaska: U.S. Geological Survey Professional Paper 512, 78 p., 6 plates.

Dickinson, W.R., 1985, Interpreting provenance relations from detrital modes of sandstones, in Zuffa, G.G., ed., Provenance of Arenites: NATO Advanced Science Institutes Series C-Mathematical and Physical Sciences, D. Reidel Publishing Co., v. 148, p. 333-361.

Dickinson, W.R., and Suczek, C.A., 1979, Plate tectonics and sandstone compositions: American Association of Petroleum Geologists Bulletin, v. 63, no. 12, p. 2,164-2,182. doi:10.1306/2F9188FB-16CE-11D7-8645000102C1865D

Gillis, R.J., ed., 2013, Overview of 2012 field studies - Upper Alaska Peninsula and west side of lower Cook Inlet, Alaska: Alaska Division of Geological \& Geophysical Surveys Preliminary Interpretive Report 2013-1, 48 p. doi:10.14509/24824

Gillis, R.J., ed., 2014, Cook Inlet program 2013 field studies-Observations and preliminary interpretations from new 1:63,360-scale geologic mapping of the Iniskin Peninsula, lower Cook Inlet, Alaska: Alaska Division of Geological \& Geophysical Surveys Preliminary Interpretive Report 2014-2, 31 p. doi:10.14509/27303

Helmold, K.P., and Stanley, R.G., 2015, Petrology and reservoir quality of the Gaikema Sandstone-Initial impressions, in Wartes, M.A., Energy-related studies during the 2014 field season, western Cook Inlet, Alaska: Alaska Division of Geological \& Geophysical Surveys Preliminary Interpretive Report 2015-5-7, p. 43-48. doi:10.14509/29462

Herriott, T.M., ed., 2016 (this volume), Petroleum-related geologic studies in lower Cook Inlet during 2015, Iniskin-Tuxedni region, south-central Alaska: Alaska Division of Geological \& Geophysical Surveys Preliminary Interpretive Report 2016-1, 78 p. doi: $10.14509 / 29532$

LePain, D.L., and Stanley, R.G., 2015, Stratigraphic reconnaissance of the Middle Jurassic Red Glacier Formation, Tuxedni Group, at Red Glacier, Cook Inlet, Alaska, in Wartes, M.A., ed., Energy-related studies of the 2014 field season, western Cook Inlet, Alaska: Alaska Division of Geological \& Geophysical Surveys Preliminary Interpretive Report 2015-5-5, p. 23-28. doi: $\underline{10.14509 / 29460}$

LePain, D.L., Stanley, R.G., Helmold, K.P., and Shellenbaum, D.P., 2013, Geologic framework and petroleum systems of Cook Inlet basin, south-central Alaska, in Stone, D.M., and Hite, D.M., eds., Oil and Gas Fields of the Cook Inlet Basin: American Association of Petroleum Geologists Memoir 104, p. 37-116.

LePain, D.L., Stanley, R.G., and Helmold, K.P., 2016 (this volume), Reconnaissance stratigraphy of the Red Glacier Formation (Middle Jurassic) near Hungryman Creek, Cook Inlet basin, Alaska, in Herriott, T.M., ed., Petroleum-related geologic studies in lower Cook Inlet during 2015, Iniskin-Tuxedni region, south-central Alaska: Alaska Division of Geological \& Geophysical Surveys Preliminary Interpretive Report 2016-1, p. 21-31, doi:10.14509/29536

Magoon, L.B., 1994, Tuxedni-Hemlock(!) petroleum system in the Cook Inlet, Alaska, U.S.A., in Magoon, L.B., and Dow, W.G., eds., The petroleum system - from source to trap: American Association of Petroleum Geologists Memoir 60, p. 359-370.

Nordeng, S.H., 2009, The Bakken petroleum system - An example of a continuous petroleum accumulation: Industrial Commission of North Dakota, Department of Mineral Resources, DMR Newsletter, v. 36, p. 21-24.

Pittman, E.D., and Larese, R.E., 1991, Compaction of lithic sands-Experimental results and applications: American Association of Petroleum Geologists Bulletin, v. 75, no. 8, p. 1,279-1,299.

Wartes, M.A., ed., 2015, Energy-related studies during the 2014 field season, western Cook Inlet, Alaska: Alaska Division of Geological \& Geophysical Surveys Preliminary Interpretive Report 2015-5, 62 p. doi:10.14509/29455 